\title{
PENERAPAN PP 46 TAHUN 2013 DALAM ANALISIS CVP UNTUK MEMBANTU PERENCANAAN DAN PENGAMBILAN KEPUTUSAN UMKM
}

\author{
Norman Duma Sitinjak ${ }^{1^{*}}$ \\ ${ }^{1}$ Fakultas Ekonomi dan Bisnis, Universitas Merdeka Malang \\ *noma1274@yahoo.com
}

\begin{abstract}
To increase state revenue and help SMEs in the calculation of the tax, the Government of Indonesia issued PP 46 2013. That regulation tax is for businesses with gross earnings in a tax year less than Rp. 4.8 billion. It will be charged by $1 \%$ tax rate on gross income. Tax will become a variable cost considered by the way it is calculated. So that the SMEs are able to include PP 462013 as a component of Cost Volume Profit Analysis in making a plan and decision
\end{abstract}

Keywords: PP 46 2013, Variable Cost , Cost Volume Profit Analysis

\section{PENDAHULUAN}

Setiap kegiatan lebih baik diawali dengan perencanaan agar dapat berjalan lebih baik, termasuk dalam kegiatan berwirausaha. Perencanaan bermanfaat dalam pembentukan standar sehingga kegiatan wirausaha tersebut memiliki tolak ukur. Perencanaan bermanfaat dalam membantu pengusaha dalam memilih berbagai alternatif. Selain itu perencanaan juga bermanfaat dalam membantu perusahaan menghadapi perubahan yang terjadi baik yang berasal dari eksternal dan internal. UMKM yang merupakan usaha skala menengah ke bawah juga memerlukan perencanaan, bahkan dapat dikatakan lebih memerlukan dibanding perusahaan besar jika dilihat dari kemampuan modal. Dasar pemikirannya adalah jika perusahaan besar mengalami kesalahan perencanaan maka dampaknya tidak langsung menutup usaha. Berbeda dengan UMKM. Seperti diketahui, permasalahan yang hampir dialami semua UMKM adalah ketersediaan modal atau dana. Sehingga jika dihubungkan dengan kesalahan perencanaan maka UMKM sangat merasakannya sehingga dampak sampai titik tutup usaha akan lebih cepat terjadi.

Para pelaku UMKM walaupun tidak memahami tentang istilah Analisis Cost Volume Profit (CVP) sebetulnya telah menggunakan teknis penghitungannya. Hal Itu dapat diketahui dari istilah yang sering dipakai yaitu "biayanya tetap" dan "biayanya berubah sesuai produksi". "Biaya yang berubah sesuai produksi” atau biaya variabel untuk perusahaan manufaktur terdiri dari biaya bahan baku, biaya tenaga kerja langung dan biaya overhead pabrik. Biaya tetap dapat terdiri dari gaji, biaya sewa, dan lainnya.

Analisis Cost Volume Profit (CVP) yang terdiri dari empat variabel (volume penjualan, biaya variabel, biaya tetap dan harga jual (Yuan, 2009) sangat bermanfaat bagi perusahaan dalam melakukan perencanaan. Melalui CVP perusahaan dapat merencanakan titik impas, pemilihan permintaan penjualan dan lainnya. Sebelum berlakunya PP 46 Tahun 2013 atau sering disebut dengan pajak UMKM, yaitu pajak untuk usaha yang omzet brutonya dalam setahun dibawah Rp. 4,8 Miliar, biaya pajak 
tidak digunakan sebagai komponen dalam penerapan CVP. Akan tetapi setelah Pajak UMKM diterapkan maka pajak tersebut dapat digunakan. Dasar pemikirannya adalah karena pajaknya dihitung atas dasar omzet bruto yang dikalikan dengan 1\%. Sehingga biaya PPh dapat dikelompokkan ke dalam biaya variabel.

PP 46 tahun 2013 diterbitkan untuk meringankan UMKM dalam menjalankan kewajiban perpajakannya. sehingga kepatuhan pajak UMKM semakin meningkat. Bentuk kepatuhan tersebut diantaranya ialah memiliki Nomor Pokok Wajib pajak (NPWP). Peningkatan kepatuhan UMKM diharapkan dapat membantu pemerintah dalam meningkatkan penerimaan pajak.

Perhitungan PPh secara praktis yang dimaksud setelah diterbitkan PP 46 tahun 2013 adalah karena Wajib pajak (WP) UMKM dalam menghitung PPh nya tinggal mengalikan omzet brutonya dengan tarif $1 \%$.

Metode penghitungan $\mathrm{PPh}$ yang praktis tersebut pada satu sisi sangat membantu UMKM dalam penghitungannya, tetapi pada sisi yang lain UMKM harus lebih berhatihati dalam menentukan harga jual dan unit penjualan. Maksudnya adalah pengusaha sebaiknya dapat dengan benar merencanakan batas minimal penjualan agar omzet yang dicapai mampu menghasilkan laba. Jika belum melewati batas minimal penjualan maka omzet belum menghasilkan laba. Dengan kata lain, UMKM yang omzetnya belum “aman" akan terhutang pajak pada kondisi yang masih rugi. Ingat $1 \%$ bukan dikali dengan laba bersih, melainkan dengan omzet bruto.

UMKM yang berada pada kondisi tersebut akan mengalami financial distress karena keuangan masih lemah akan tetapi biaya bertambah. Jika kondisi ini terus dialami maka UMKM tersebut tidak menunggu waktu lama untuk berganti nama.

\section{Biaya Variabel}

Biaya variabel menurut Carter dan Usry (2006) biaya yang besarannya secara total mengalami perubahan seiring perubahan aktivitas. Biaya variabel dapat dibagi lagi menjadi biaya variabel produksi dan non produksi.

\section{Analisis CVP}

Hansen \& Mowen (2005) menyampaikan bahwa analisis biaya volume laba (analisis cost volume profit analysis) membantu perusahaan dalam melakukan perencanaan dan pengambilan keputusan, baik dalam perencanaan penjualan, biaya, penghasilan dan pengambilan keputusan dalam menerima atau menolak suatu pesanan.

Pengguna analisis CVP sangat dibantu dalam memahami hubungan antara biaya, volume dan laba yang berasal dari interaksi antara bauran produk dijual, biaya, tetap, baiaya variabel, volume dan harga jual. Setelah memahami hubungan antara biaya, volume dan laba, selanjutnya pengguna dapat melakukan perencanaan dan pengambilan keputusan dengan benar.

Penggunaan analisis CVP harus didasarkan pada asumsi tertentu agar dapat berjalan dengan efektif. Menurut Garrrison dkk (2006: 350) asumsi-asumsi tersebut diantaranya adalah: 1) Harga yang konstan untuk masa tertentu; 2) Biaya dapat dibagi menjadi dua yaitu variabel dan tetap; 3) Perusahaan yang menghasilkan berbagai jenis produk, bauran penjualannya adalah konstan untuk masa waktu tertentu.

Analisis CVP secara teknis sangat membantu pengguna dalam melakukan penghitungan:

\section{a. Break Even Point (BEP)}

BEP adalah suatu titik dimana penjualan menghasilkan laba yang besarnya Rp. 0,karena belum menghasilkan laba tetapi sudah tidak lagi mengalami kerugian. Dalam kata lain besarnya pendapatan sama dengan biaya. Adapun rumus BEP adalah sebagai berikut:

$$
\mathrm{BEP}=\frac{\text { Biaya Tetap }}{\text { Harga Jual/unit - Biaya Variabel/unit }}
$$


BEP sangat membantu pengguna dalam merencanakan berapa unit penjualan yang harus dicapai agar tidak lagi rugi walau belum memperoleh laba. Setelah itu dapat menghitung berapa penjualan (unit) yang diperlukan untuk mencapai keuntungan yang diinginkan dengan rumus sebagai berikut:

Penjualan $=\frac{\text { Biaya Tetap }+ \text { Laba diinginkan }}{\text { Harga Jual/unit }- \text { Biaya Variabel/unit }}$

Untuk menghitung lamanya waktu (bulan) mencapai keuntungan yang diinginkan dengan rumus sebagai berikut :

Waktu (bulan) $=\frac{\text { Penjualan Yang Diinginkan }}{\text { Rata2 Penjualan Per Bulan }}$

Penghitungan waktu yang diperlukan untuk memperoleh laba yang diinginkan perlu diketahui terutama karena UMKM secara umum memiliki modal yang tidak banyak. Bahkan inilah salah satu kelemahan dari UMKM yaitu ketersediaan modal.

b. Titik Tutup Usaha (Shut Down Point) Perhitungan ini perlu dilakukan sebagai salah satu indikator selain kekuatan modal dan ketersediaan industri hulu untuk menilai apakah suatu usaha sudah tidak layak lagi dijalankan dengan rumus sebagai berikut :

$$
\mathrm{SDP}=\frac{\text { Biaya Tetap Tunai }}{\text { Harga Jual/unit }- \text { Biaya Variabel/unit }}
$$

c. Menerima atau Menolak Pesanan Khusus Penerapan analisis CVP akan membantu pengguna dalam mengambil keputusan menolak atau menerima pesanan khusus. Hal ini dapat diterapkan dengan asumsi perusahaan berproduksi dibawah kapasistas produksi maksimumnya.

\section{PP 46 tahun 2013}

Peraturan pajak ini bertujuan untuk kesederhanaan, meningkatkan pengetahuan masyarakat tentang manfaat pajak, adanya konstrol sosial dalam memenuhi kewajiban perpajakan. Sederhana maksudnya adalah pajak terutang yang harus dibayar adalah sebesar $1 \%$ dari peredaran bruto.

Peraturan ini sering disebut sebagai Pajak UMKM karena yang menjadi subjek pajak adalah Orang Pribadi (OP), badan (tidak termasuk BUT) yang peredaran brutonya tidak melebihi dari Rp. 4,8 miliar dalam satu tahun pajak. Usaha yang omzet per tahun tidak melebihi dari Rp. 4,8 miliar termasuk kategori UMKM.

Non objek pajak PP 462013 adalah penghasilan dari jasa sehubungan dengan pekerjaan bebas dan penghasilan dari usaha dagang dan jasa yang dikenai PPh final, misalnya sewa kamar kos, sewa rumah dan lai-lain.

\section{PEMBAHASAN \\ PP 462013 Sebagai Biaya Variabel}

Merujuk kepada definisi biaya variabel, PP 46 tahun 2013 juga dapat dikatakan sebagai biaya variabel untuk subjek pajak yang melakukan usaha. Dasar pemikirannya adalah tarif pajak yang 1\% didasarkan atas peredaran bruto. Sehingga, besaran pajak terutang akan mengikuti besaran penjualan bruto. Semakin besar penjualan maka semakin besar pula $\mathrm{PPh}$ yang terutang.

Maksimum tarif 1\% akan berhenti pada peredaran bruto Rp. 4,8 miliar dalam satu tahun pajak. Jika telah melebihi Rp. 4,8 miliar dalam satu tahun pajak maka penghitungannya kembali pada metode untuk WP OP dan WP Badan.

Besaran penjualan sampai dengan Rp 4,8 Miliar dalam satu tahun pajak masih dikenakan tariff $1 \%$. Sehingga, jika dalam perhitungan BEP tidak mengikutsertakan pajak PP 46 Tahun 2013 maka hasil perhitungan tersebut mengandung kerugian. Jika perhitungan BEP mengikutsertakan pajak tersebut maka UMKM lebih mudah dalam melakukan perencanaan dan pengambilan keputusan. 
Untuk perhitungan pajak WP OP dan WP Badan yang diluar kriteria PP 46 Tahun 2013 metode penghitungan pajaknya berbeda. Sehingga PPh-nya tidak dapat diterapkan sebagai biaya variable. Secara ringkas dijelaskan, untuk perhitungan $\mathrm{PPh}$ WP OP penghasilannya harus diatas Penghasilan Tidak Kena Pajak (PTKP), dan untuk perhitungan $\mathrm{PPh}$ WP Badan penghasilannya harus mengahasilkan laba bersih sebelum pajak.

\section{PP 46 tahun 2013 Sebagai Komponen Analisis CVP}

Pengelola perusahaan perlu melakukan perencanaan dan pengambilan keputusan. Disinilah Analisis CVP memiliki peran. Sebagai simulasi akan diberikan contoh;

$\begin{array}{llr}\text { Biaya tetap } & =\text { Rp. } & 60.000 .000 \\ \text { Harga jual/unit } & =\text { Rp. } & 15.000 \\ \text { Biaya variabel/unit } & =\text { Rp } & 12.000 \\ \text { (Blm termasuk PPh 1\%) } & \end{array}$

Perhitungan BEP sebagai berikut:

$\mathrm{BEP}=\frac{60.000 .000}{15.000-12.000}$
$\mathrm{BEP}=$

Berdasarkan simulasi di atas diperoleh BEP adalah pada penjualan 20.000 unit. Berikutnya adalah simulasi jika PP 462013 ikut sebagai komponen biaya variabel.

$$
\begin{array}{llr}
\text { Biaya tetap } & =\text { Rp. } & 60.000 .000 \\
\text { Harga jual/unit } & =\text { Rp. } & 15.000 \\
\text { Biaya variabel/unit } & =\text { Rp } & 12.120
\end{array}
$$$$
\mathrm{BEP}=\quad \frac{60.000 .000}{15.000-12.120}
$$$$
\text { BEP }=\quad 20.833 \text { unit }
$$

Setelah komponen PPh diikutsertakan ke dalam Analisis CVP maka BEP nya naik dari 20.000 unit menjadi 20.833 unit. Ada kenaikan sebesar 833 unit. Dari sini pihak UMKM dapat mengambil keputusan : 1) Menaikkan harga jual agar BEP nya kembali ke 20.000 unit; 2) Kondisi harga tetap akan tetapi waktu untuk mencapai BEP bertambah. Jika PP $46 \quad 2013$ tidak diikutsertakan kedalam analisis CVP maka perusahaan akan mengalami kesalahan penghitungan BEP. Pada kondisi kekuatan modal kuat hal tersebut mungkin tidak menjadi masalah yang serius, akan tetapi jika kekuatan modal adalah lemah maka kesalahan penghitungan akan menimbulkan gangguan keuangan pad UMKM tersebut.

Kalkulasi tersebut juga berlaku dalam penentuan jumlah unit yang harus dijual untuk mecapai laba yang diinginkan. Jika PP 462013 tidak diikutsertakan maka UMKM tersebut akan salah dalam penghitungan unit yang harus dijual. Kondisi inilah yang sering dialami oleh perusahaan yang salah dalam penghitungan. Merasa sudah memperoleh keuntungan yang diinginkan akan tetapi keuangan perusahaan semakin berkurang.

Berikutnya simulasi penggunaan PP 46 Tahun 2013 dalam penentuan penjualan (unit) untuk mencapai laba yang diinginkan. Masih menggunakan data yang sama, berikut simulasinya jika PP 46 Tahun 2013 tidak sebagai biaya variabel:
Biaya tetap
$=$ Rp. 60.000.000
Harga jual/unit $\quad=$ Rp. $\quad 15.000$
Biaya variabel/unit $=\mathrm{Rp} \quad 12.000$

(Blm termasuk PPh 1\%)

Laba yang diinginkan $=\mathrm{Rp} \quad 6.000 .000$

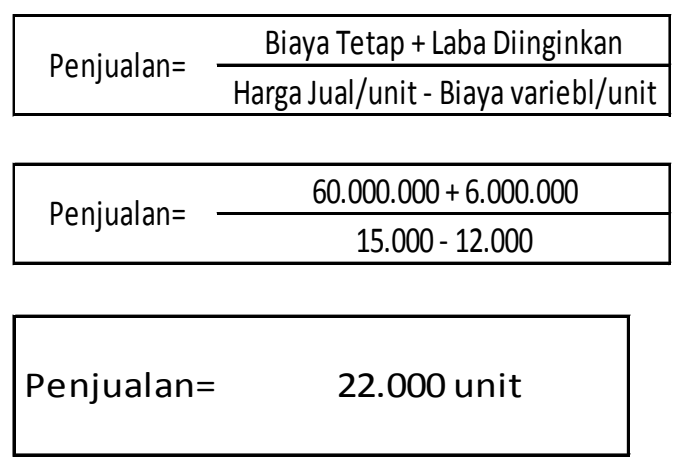

Berikut simulasinya jika PP 46 Tahun 2013 sebagai biaya variabel

$\begin{array}{llr}\text { Biaya tetap } & \text { Rp. } 60.000 .000 \\ \text { Harga jual/unit } & =\text { Rp. } \quad 15.000\end{array}$ 
Biaya variabel/unit $\quad=\mathrm{Rp} \quad 12.120$ (sudah termasuk PPh 1\%) Laba yang diinginkan $=\mathrm{Rp} \quad 6.000 .000$

\begin{tabular}{|c|c|}
\hline \multirow{2}{*}{ Penjualan= } & Biaya Tetap + Laba Diinginkan \\
\hline & Harga Jual/unit - Biaya variabel/unit \\
\hline
\end{tabular}

\begin{tabular}{|c|}
\hline Penjualan $=$ \\
\cline { 2 - 2 }
\end{tabular}

Penjualan $=22.917$ unit

Berdasarkan perhitungan di atas diketahui perbedaan penjualan dalam unit sebelum dan sesudah menggunakan PP 46 Tahun 2013 sebagai biaya variable.

\section{Kesimpulan}

Kesimpulan yang dapat diambil adalah sebagai berikut: 1) UMKM juga perlu menerapkan analisis CVP untuk membantu dalam perencanaan dan pengambilan keputusan; 2) UMKM yang omzet brutonya sebesar Rp. 4,8 miliar kebawah dalam satu tahun pajak perlu mengikutsertakan PP 46 tahun 2013 sebagai komponen biaya variabel; 3) Penentuan BEP dan Unit yang harus dijual jika mengikutsertakan PP 46Tahun 2013 akan menghasilkan unit yang lebih besar dibandingkan jika tidak mengikutsertakannya.

\section{DAFTAR PUSTAKA}

Anderson, J. A. dan Leese, W. R. (2016). “A Formula For The Units To Satisfy An Operation's Desired Rate Of Return In CVP Analysis - A Conceptual Approach." American Journal of Business Education - Second Quarter. 9(2)

Carter dan Usry. (2006). Cost Accounting (Akuntansi Biaya). Edisi 13. Salemba Empat, Jakarta

Chan, Y. L. dan Yuan, Y. (1990). “Dealing with Fuzziness in Cost-Volume-Profit Analysis." Accounting and Business Research. 20.
Choo, F. dan Tan, K. B. (2011). “An Income Statement Teaching Approach for Cost-Volume-Profit (CVP) Analysis by Using a Company's CVP Model.” Journal of Accounting and Finance, 11 (4)

Garrison, R. H., Noreen dan Brewer. (2006). Akuntansi Manajerial Buku 1. Edisi 11. Terjemahan oleh Nuri Hinduan. Salemba Empat, Jakarta

Hansen dan Mowen. (2005). Management Accounting. Buku 2. Edisi ke 7. Salemba Empat, Jakarta

Isroah. (2013). "Perhitungan Pajak Penghasilan Bagi UMKM.” $\underline{\text { Jurnal }}$ Nominal, II(1).

Republik Indonesia. (2013). Peraturan Pemerintah Republik Indonesia Nomor 46 Tahun 2013. Pajak Penghasilan Atas Penghasilan Dari Usaha Yang Diterima Atau Diperoleh Wajib Pajak Yang Memiliki Peredaran Bruto Tertentu

Yuan, F. C. (2009). "The use of a fuzzy logic-based system in cost-volumeprofit analysis under uncertainty. Expert Systems with Applications.” 36 